\title{
INTERNALISASI NILAI MULTIKULUTURAL DALAM MENGEMBANGKAN SIKAP TOLERANSI ( Studi di Di Pesantren Mahasiswa Universitas Islam Malang)
}

\author{
Muhammad Anas Ma'Arif \\ Institut Pesantren KH Abdul Chalim Mojokerto \\ Email: anasdt16@gmail.com
}

\begin{abstract}
Abstrak
Pentingnya menumbuhkan sikap toleransi diberbagai kalangan yang akan membentuk keharmonisan disetiap aspek. Hal ini di tunjukan disetiap Pesantren yang ada di Indonesia. Pesantren selalu menampakkan wajah toleransi, ramah tamah dan menerima berbagai kalangan suku dan budaya. Termasuk Pesantren Mahasiswa Universitas Islam Malang. Hal itu dinampakan dengan segala kegiatan yang dilaksanakan baik secara kurikuler atau ko kurikuler. Ditunjang dengan jargon bahwa Unisma merupakan Kampus Multikultural dengan sebab itulah pentingnya penelitian ini dilaksanakan. Penelitian ini berusaha menganalisis dan mendeskripsikan proses internalisasi yang dilakukan Pesantren mahasiswa Unisma dan implikasi yang dirasakan oleh mahasiswa dan lingkungan sekitar terhadap proses internalisasi nilai multikultural yang diterapkan oleh Pesantren Unisma. Penelitian ini menggunakan jenis penelitian kualitatif dengan pendekatan studi kasus. Peneliti hanya mengungkapkan proses dan implikasi internalisasi dengan tehnik analisis data yang diperoleh dari wawancara kepada kepala Pesantren, santri, masyarakat dan dosen Unisma serta dokumentasi dan observasi yang mendalam. Hasil penelitian ini adalah Hasil penelitian menunjukkan, bahwa: 1) prinsip-prinsip penanaman nilai-nilai pendidikan multikultural di Unisma didasarkan pada beberapa prinsip, yaitu: keterbukaan (openness), toleransi (tolerance), bersatu dalam perbedaan (unity in diversity), dan Islam rahmatan lil'alamin sebagai leader; 2) implementasi penanaman nilai-nilai pendidikan multikultural di Unisma terpolakan menjadi dua, yaitu multicultural knowing dan multicultural feeling. Multicultural
\end{abstract}


knowing diberikan melalui beberapa kegiatan seperti Orientasi Kehidupan Kampus Mahasiswa Baru (Oshika Maba), Halaqoh Diniyah, dan Mata Kuliah Agama Islam 1-5. Adapun multicultural feeling ditanamkan melalui kegiatan student day; dan 3) penanaman nilai-nilai pendidikan multikultural di Unisma memiliki implikasi yang positif terhadap sikap toleransi para mahasiswa Unisma.

Kata Kunci: Internalisasi, Nilai Multikultural, Toleransi, Pesantren Mahasiswa.

\section{A. Pendahuluan}

Mahasiswa merupakan darah muda yang mempunyai semangat yang tinggi dalam menemukan jati dirinya. Termasuk dalam bertindak, mahasiswa selalu merasa dirinya paling benar apalagi mereka lebih mengunggulkan golongan tertentu dan sikap inklusivisme. Bahkan ketika seorang mahasiswa idealis dan fanatik sempit dimungkinkan akan muncul sikap intoleran terhadap mahasiswa lain yang tidak sama denganya.

Munculnya sikap intoleran diakibatkan kurangnya pemahaman mendalam terhadap pengetahuan agama. Yang mana mereka hanya belajar agama hanya dari permukaan kulit saja ${ }^{1}$. Hasil survei LSI (Lingkaran Survei Indonesia) tahun 2012 mengemukakan sebanyak 31 \% Indonesia saat ini sudah tidak toleran terhadap agama². Bahkan pemahaman mahasiswa dinilai rendah terhadap kebinekaan dan

\footnotetext{
1 Azyumardi Azra, 'Kontestasi Pemikiran Islam Indonesia Kontemporer', Studia Islamika 23, no. 1 (30 April 2016): 175-84, https://doi.org/10.15408/sdi.v23i1.2905.

2 Nur Wahyu Etikasari, 'Persepsi Mahasiswa Program Studi S1 Ppkn Universitas Negeri Surabaya Terhadap Wacana Intoleransi Di Media Sosial', Kajian Moral dan $\begin{array}{llllll}\text { Kewarganegaraan } & 6, & \text { no. } & 01 & \text { (25 January }\end{array}$ http://jurnalmahasiswa.unesa.ac.id/index.php/jurnal-pendidikankewarganegaraa/article/view/22679.
} 
keragaman budaya ${ }^{3}$. Hal ini menunjukan bahwa pentingnya menginternalisasikan nilai multikultural kepada seluruh elemen masyarakat terutama mahasiswa.

Dengan demikian Pentingnya internalisasi nilai multikultural di berbagai lembaga pendidikan apalagi di integrasikan dalam pembelajaran agama. Sangat penting dilakukan mengingat Indonesia terdiri dari berbagai jenis suku, budaya dan agama4. Strategi untuk menginternalisasikan juga bisa diintegrasikan dalam pembelajaran pada materi Pendidikan Islam, yang mana guru harus bisa menjadikan peserta didik toleransi dan saling menghargai ${ }^{5}$. Implementasi pendidikan multikultural terdiri dari dua aspek yaitu secara kualitatif dan kuantitatif. Secara kualitatif adalah pada impelemntasi konsep yang secara sistematis, sedangkan secara kuantitatif yaitu pendidikan multikultural belum terisolasi dengan baik terutama di lembaga tinggi (kampus) ${ }^{6}$.

Untuk pencegahan sikap intoleran dan radikalisme mahasiswa bisa dibimbing dengan intens di dalam pesantren seperti Universitas Islam Malang mengakomodir mahasiswanya agar berada dalam lingkup pesantren. Pesantren menjadi pusat kegiatan mahasiswa baik dalam

${ }^{3}$ Pengetahuan mahasiswa tentang keberagaman dan kebinekaan $45 \%$ dari seluruh mahasiswa STKIP Darussalam Cilacap belum secara benar mengetahui tentang nilai keberagaman budaya Pajar Purnomo, 'Pengembangan Buletin Kampus Bermuatan Nilai Kebhinekaan Pancasila Untuk Menangkal Radikalisme Pada Mahasiswa STKIP Darussalam Cilacap', Lingua 13, no. 2 (2017): 149.

4 Penelitian ini menghasilkan pentingnya menginternalisasikan nilai-nilai multyikultural pada setiap lembaga pendidikan. yaitu dengan cara: memberikan pemahaman kepada para guru, pengintegrasian nilai multikultutr didalam pembelajaran, strategi keeteladadan guru dengan pembiasaan dan internalisasi. Sapendi Sapendi, 'Internalisasi NilaiNilai Multikultural Dalam Pembelajaran Pendidikan Agama Islam Di Sekolah (Pendidikan Tanpa Kekerasan)', Raheema 2, no. 1 (2015): 106-7.

5 Syamsul Bahri, 'Internalisasi Nilai-Nilai Multikulturalisme Dengan Pendekatan Aditif Dalam Pembelajaran Pai Di Sekolah Dasar Taman Harapan', n.d., 143.

${ }^{6}$ Nur Efendi, 'Pengembangan Pendidikan Islam Plural-Multikultural', Ta'allum: Jurnal Pendidikan Islam 1, no. 1 (2013): 14. 
kegiatan spiritual, sosial dan pengembangan skill mahasiswa. Dalam pesantren teridiri dari berbagai mahasiswa yang mempunyai latar belakang berbeda. Mereka dibimbing diberi pengetahuan tentang pentingnya saling menghagai pendapat, menghargai perbedaan, toleransi dan kebebasan dalam bertindak asalkan sesuai dengan norma-norma yang berlaku.

Latar belakang mahasiswa di Pesantren Universitas Islam Malang berasal dari berbagai daerah dan budaya yang berbeda-beda seperti, Ambon, Papua, Borneo, Batak, Sumatra bahkan terdapat beberapa mahasiswa luar negeri dari Afganistan, Malaysia, Philipina, Tailand dan Vietnam. Perbedaan itu tidak pernah menjadikan suatu hambatan melainkan menjadi suatu kekuatan untuk mengembangkan rasa sosial yang tinggi. Karena dalam implementasinya Universitas Islam Malang mengikuti prinsip pendidikan multikultural yaitu: (1) demokrasi, kesetaraan dan keadilan. (2) berorientasi pada kemanusiaan kebersamaan dan perdamaian. (3) mengembangkan sikap mengakui, menerima dan menghargai keragaman budaya, etnis dan pendapat ${ }^{\top}$.

Dari beberapa pembahasan diatas maka timbulah beberapa pertanyaan tentang bagiamanakah internalisasi nilai multikultural di lingkungan mahasiswa? Bagiamanakah proses internalisasi? Bagiamankah model internalisasi? Dari beberapa pertanyaan tersebut kiranya penting untuk diteliti dengan judul "Internalisasi Nilai-Nilai Multikutural dalam mengembangkan karakter toleransi (studi di Pesantren Mahasiswa Universitas Islam Malang).

\footnotetext{
7 Dawam dalam Musyarofah Musyarofah, 'Internalisasi Pesan Multikultural Pada Organisasi Pesantren Putri Stain Jember', Inject (Interdisciplinary Journal of Communication) 1, no. 2 (2016): 182; Abdullah Aly, Pendidikan Islam Multikultural Di Pesantren: Telaah Terhadap Kurikulum Pondok Pesantren Modern Islam Assalam Surakarta, Cet. 1 (Yogyakarta: Pustaka Pelajar, 2011), 109.
} 


\section{B. Metode Penelitian}

Penelitian dengan tema internalisasi nilai multikultural dalam meningkatkan perilaku toleransi mahasiswa di Pesantren Mahasiswa Universitas Islam Malang menggunakan pendekatan kualitatif. Penelitian ini diarahkan untuk mengeksplorasi dan mengungkap proses internalisasi, implementasi serta model internalisasi yang diterapkan dalam pesantren mahasiswa untuk meningkatkan perilaku toleransi. Perilaku toleransi yaitu bagaimana mahasiswa bisa saling menghargai, menghargai perbedaan, persaudaraan dan kerjasama. Dalam kontek sosial demikian pendekatan kualitatif sangat cocok untuk mengakomodir penelitian ini. Karena fokusnya adalah proses maka penelitian ini bersifat alamiah dan induktif8.

Seperti yang dikemukakan Bogdan dan Taylor yang dikuti oleh Moeloeng mengenai kualitatif, prosedur penelitian ini menghasilkan data deskriptif berupa kata-kata tertulis atau lisan dari orang-orang atau perilaku yang diamati. Peneliti tidak mengisolasikan subjek penelitian atau individu kedalam variabel atau hipotesis, tetapi memandangnya sebagai bagian dari sesuatu keutuhan, yakni manusia yang memiliki kesadaran dan kehendak ${ }^{9}$. Dalam penelitian kualitatif kealamiahan latar penelitian juga diperlukan agar peneliti dapat menafsirkan proses internalisasi yang apa adanya ${ }^{10}$.

${ }^{8}$ Robert Bogdan and Sari Knopp Biklen, Qualitative Research for Education: An Introduction to Theory and Methods, 3rd ed (Boston: Allyn and Bacon, 1998), 4-7.

9 Moloeng Lexy J, Metodologi penelitian Kualitatif, 29th ed. (Bandung: Rosdakarya, 2011), 4 .

10 “...an inquiry process of understanding based on diztinct methodological tradition of inquiry that explore a social or human problem. The reseacher builds a complex, holistic picture, analyze words, report detail views of infromants, and conduct the study in a natural setting”. John W. Creswell, Educational Researcb: Planning, Conducting, and Evaluating Quantitative and Qualitative Research, 4th ed (Boston: Pearson, 2012), 15; Peneliti tidak boleh 
Adapun jenis penelitian ini menggunakan studi kasus dengan alasan karena penelitian ini dilakukan terhadap suatu kesatuan sistem, yang berupa program, kegiatan peristiwa atau sekelompok individu yang terikat tempat, tempat, waktu atau ikatan tertentu ${ }^{11}$ yaitu Pesantren Mahasiswa Unisma Malang. Yin menyebutkan bahwa studi kasus merupakan penelitian naturalistik yang menyelidiki fenomena dalam konteks kehidupan nyata dan memanfaatkan multisumber bukti ${ }^{12}$.

Peneliti akan mempelajari dan mengungkap semaksimal mungkin tentang proses internalisasi nilai multikultural untuk meningkatkan perilaku mahasiswa di Pesantren Mahasiswa Universitas Islam Malang Peneliti juga akan meyajikan deskripsi lengkap tentang proses internalisasi nilai multikultural.

Untuk mendapatkan data yang maksimal maka diperlukan tehnik yang tepat agar penelitian ini sesuai yang diharakan oleh peneliti.
a. Pengamatan peran serta (partisipant observatory)
b. Wawancara mendalam, (indept interview)
c. Dokumentasi

Karena data penelitian ini berupa data kualitatif (antara lain berupa pernyataan, gejala, tindakan nonverbal yang dapat terekam

dan tidak akan memanipulasi dan merekayasa gejala dan situasi yang ada. Naturalistic inquiry ini berbeda dengan penelitian yang dibuat dengan cara ekperimen yang terkontrol. (controlled-experiment design) JR Raco, Metode penelitian Kuantitatif Jenis, Karakteristik dan Keunggulanya (Bandung: Alfabeta, 2014), 10.

11 Norman K. Denzin and Yvonna S. Lincoln, eds., The SAGE Handbook of Qualitative Research, 3rd ed (Thousand Oaks: Sage Publications, 2005), 236.

12 Robert K Yin, Case Study Research: Design and Methods, 2013, 16. 
oleh deskripsi kalimat atau oleh gambar) maka terdapat tiga alur kegiatan yang dapat dilakukan secara bersamaan, yaitu ${ }^{13}$ :

1. Reduksi data ialah proses pemilihan pemusatan perhatian pada penyederhanaan. Pengabstrakan dan transformasi data kasar yang muncul dari catatan-catatan yang diperoleh secara tertulis di lapangan. Data tersebut disederhanakan dan dibuat ringkasan-ringkasan singkat.

2. Penyajian data merupakan sekumpulan infromasi yang memungkinkan pada tahap selanjutnya yaitu penarikan infromasi dan pengambilan tindakan. Peneliti menggunakan cara yang menggunakan matriks teks, grafik jaringan dan bagan disamping juga membutuhkan teks naratif.

3. Penarikan kesimpulan atau verifikasi. Verifiksi data dilapangan sehingga menimbulkan kesimpulan yang benarbanar tidak ada subjektifitas penulis.

\section{Hasil dan Pembahasan}

\section{Nilai yang di internalisasikan dan prosesnya}

Tabel berikut akan memberikan gambaran yang lebih jelas terkait dengan nilai-nilai yang diajarkan di Pesma yang didalamnya termuat nilai-nilai pendidikan multikultural.

\begin{tabular}{|l|l|l|l|}
\hline & $\begin{array}{l}\text { Nilai } \\
\text { Pesantren }\end{array}$ & $\begin{array}{l}\text { Nilai } \\
\text { Multikultural }\end{array}$ & \\
\hline 1 & Keikhlasan & Nilai & Keikhlasan juga berarti rame \\
& & demokrasi dan & ing gawe, maksudnya sibuk \\
keadilan & $\begin{array}{l}\text { bekerja untuk melaksanakan } \\
\text { tugas-tugas yang luhur seperti }\end{array}$ \\
& & & \\
\hline
\end{tabular}

13 Matthew B. Miles, A. M. Huberman, and Johnny Saldaña, Qualitative Data Analysis: A Methods Sourcebook, Third edition (Thousand Oaks, Califorinia: SAGE Publications, Inc, 2014), 18. 


\begin{tabular}{|c|c|c|c|}
\hline & & & $\begin{array}{l}\text { menegakkan kebenaran, } \\
\text { keadilan, } \\
\text { bersama, kemerdekaan dari } \\
\text { kezaliman, pencapaian ilmu } \\
\text { pengetahuan, akhlaq }\end{array}$ \\
\hline 2 & $\begin{array}{l}\text { Keiklasan } \\
\text { pengurus } \\
\text { pondok para } \\
\text { pengurus }\end{array}$ & Nilai keadilan & $\begin{array}{l}\text { Mereka adalah orang yang } \\
\text { mengerti bahwa pondok } \\
\text { pesantren bukanlah tempat } \\
\text { mencari kekayaan, melainkan } \\
\text { tempat beramal dan berjuang. } \\
\text { Mereka mengerti bahwa niat } \\
\text { mereka bekerja di pondok } \\
\text { pesantren adalah untuk } \\
\text { menghidupkan pondok, } \\
\text { bukan untuk mencari } \\
\text { penghidupan. }\end{array}$ \\
\hline 3 & $\begin{array}{l}\text { Kesederhanaan } \\
\text { dalam } \\
\text { berpakaian, } \\
\text { tempat, } \\
\text { makanan, } \\
\text { tingkah laku }\end{array}$ & Nilai Keadilan & $\begin{array}{l}\text { Kesederhanaan juga berarti } \\
\text { kewajaran, berada di tengah- } \\
\text { tengah antara dua hal yang } \\
\text { berlebihan atau antara dua } \\
\text { keadaan ekstrim, wasathoh } \\
\text { atau basathoh, tidak kikir dan } \\
\text { tidak boros, tidak kurang dan } \\
\text { tidak melampaui batas }\end{array}$ \\
\hline 4 & kebersamaan & $\begin{array}{l}\text { Toleransi dan } \\
\text { demokrasi }\end{array}$ & $\begin{array}{l}\text { Kebersamaan di pondok } \\
\text { pesantren dengan aneka watak } \\
\text { dan latar belakang } \\
\text { sosiokultural itu terjalin di } \\
\text { bawah naungan satu agama, } \\
\text { maka kebersamaan itu adalah }\end{array}$ \\
\hline
\end{tabular}




\begin{tabular}{|l|l|l|}
\hline & $\begin{array}{l}\text { ukhuwah islamiyah atau } \\
\text { persaudaran seagama yang } \\
\text { dilandasi oleh cinta dan kasih } \\
\text { sayang seagama. Santri yang } \\
\text { lebih muda menghormati } \\
\text { santri yang lebih tua. Junior } \\
\text { menghargai dan ingin } \\
\text { meneladani kebaikan dan } \\
\text { kesuksesan senior. Sementara } \\
\text { senior mengasihi dan } \\
\text { membimbing junior. }\end{array}$ \\
\hline
\end{tabular}

Dari tabel di atas, dapat diketahui bahwa nilai-nilai kejiwaan pondok pesantren yang di dalamnya sarat akan nilai-nilai pendidikan multikultural selalu ditanamkan oleh pengurus dan manajemen Pesma Unisma.

Upaya ke arah implementasi penanaman nilai-nilai pendidikan multikultural yang ada di Pesma Unisma ini tidak hanya berhenti pada tara menumbuhkan pengetahuan akan multikultural dalam diri santri. Lebih dari itu, Pesma Unisma juga mengupayakan internalisasi nilainilai multikultural yang telah dimiliki santri melalui beberapa program yang telah disebutkan sebelumnya dalam kehidupan sehari-hari. Berikut adalah kegiatan disiplin mahasiswa Pesma Unisma.

\begin{tabular}{|l|l|l|l|}
\hline No & $\begin{array}{l}\text { Disiplin di } \\
\text { Pesma } \\
\text { Unisma }\end{array}$ & $\begin{array}{l}\text { Nilai } \\
\text { Multikultural }\end{array}$ & deskripsi \\
\hline 1 & $\begin{array}{l}\text { Salat } \\
\text { berjamaah }\end{array}$ & $\begin{array}{l}\text { Kesetaraan dan } \\
\text { keadilan }\end{array}$ & $\begin{array}{l}\text { Wajib salat berjamaah di masjid } \\
\text { bagi santri yang berada di }\end{array}$ \\
\hline
\end{tabular}




\begin{tabular}{|c|c|c|c|}
\hline & & & Pesma. \\
\hline 2 & $\begin{array}{l}\text { Berpakain } \\
\text { sopan }\end{array}$ & $\begin{array}{l}\text { Kesetaraan dan } \\
\text { saling } \\
\text { menghargai }\end{array}$ & $\begin{array}{l}\text { Santri dibiasakan hidup } \\
\text { sederhana dalam berpaikaian. } \\
\text { Memakai songkok dan sarung } \\
\text { saat segala kegiatan di } \\
\text { Pesantren }\end{array}$ \\
\hline 3 & Tepat waktu & $\begin{array}{l}\text { Keadilan dan } \\
\text { toleransi }\end{array}$ & $\begin{array}{l}\text { Mahasiswa terbiasa mengatur } \\
\text { waktu dimana mereka kuliah di } \\
\text { kampus dan dimana mereka } \\
\text { berada di pesantren. }\end{array}$ \\
\hline 4 & bergaul & $\begin{array}{l}\text { Toleransi dan } \\
\text { saling } \\
\text { menghagai }\end{array}$ & $\begin{array}{l}\text { Diskusi dan bergaul dengan } \\
\text { sesama teman membiasakan } \\
\text { mahasiswa untuk berinteraksi } \\
\text { dengan sopan dan saling } \\
\text { menghargai }\end{array}$ \\
\hline 5 & berbahasa & $\begin{array}{l}\text { Keadilan dan } \\
\text { saling } \\
\text { menghargai }\end{array}$ & $\begin{array}{l}\text { Kebiasaan berbahasa dan } \\
\text { berinteraksi dengan bahasa } \\
\text { yang sopan. }\end{array}$ \\
\hline
\end{tabular}

Dirangkum dari dokumentasi keseharian Pesma Unisma

Segala keseharian mahasiswa diatas dikontrol oleh pengurus agar mereka terbiasa melakukan dengan istiqomah dan ajeg. Karena kebiasaan-kebiasaan tersebut harus di biasakan sejak dini agar memunculkan kesadaran untuk bertindak.

Pada akhirnya, disiplin ini dilaksanakan Pesma Unisma dalam rangka menumbuhkan "rasa multikultural" (transaksi nilai multikultural). Dalam artian selangkah lebih maju dari hanya sekedar tahu bahwa realitas keragaman budaya yang ada di sekitarnya hendaknya diterima dengan positif. Melainkan lebih dari itu, santri Pesma Unisma juga membenarkan yang mereka ketahui itu. Dengan 
demikian, diharapkan apa yang menjadi nilai-nilai pendidikan multikultural itu benar-benar terinternalisasi di dalam dirinya.

\section{Imlementasi Internalisasi Nilai Multikultural di Pesma Unisma}

James A. Banks ${ }^{14}$, menyatakan bahwa dalam pendidikan multikultural, setidaknya terdapat empat pendekatan yang dapat digunakan, yaitu: pertama, pendekatan kontributif. Pendekatan ini dilakukan dengan cara melakukan seleksi terhadap buku-buku teks wajib atau anjuran dan aktifitas-aktifitas tertentu seperti hari-hari besar kenegaraan dan keagamaan dari berbagai macam kebudayaan. Tujuan dari pendekatan ini adalah untuk meningkatkan pengetahuan mengenai keragaman kelompok, sehingga dapat dikembangkan dengan cara menawarkan muatan khas yang dapat dengan segera diakui dalam berbagai varian pendidikan multikultural, misalnya menggabungkan peringatan hari-hari besar keagamaan dengan hari kepahlawanan nasional.

Kedua, pendekatan aditif, yaitu dengan penambahan muatanmuatan, tema-tema, dan perspektif-perspektif ke dalam kurikulum tanpa mengubah struktur dasarnya. Dengan kata lain, pendekatan ini melibatkan upaya memasukkan literatur oleh dan tentang masyarakat dari berbagai kebudayaan ke dalam mainstream kurikulum. Misalnya, memanfaatkan muatan khas multikultural seperti tema-tema tentang koeksistensi, pro eksistensi, saling menghargai, saling memahami sebagai pemerkaya bahan ajar.

Ketiga, pendekatan transformatif. Berbeda dengan pendekatan aditif, pada pendekatan transformatif ini, kurikulum yang digunakan adalah kurikulum yang sengaja di desain dengan memasukkan di

\footnotetext{
14 James A. Banks, An Introduction to Multicultural Education, Sixth edition (Boston: Pearson Education, 2017), 30.
} 
dalamnya konsep-konsep, isu-isu, serta permasalahan-permasalahan terkait multikultural yang didekati dengan pendekatan muqaran (perbandingan) untuk memperbaharui pemahaman dan berbagai perspektif serta sudut pandang. Adapun tujuan dari pendekatan ini adalah untuk membuka perspektif kelompok-kelompok yang berbeda secara budaya (outsider) untuk memberi komentar dan penjelasan terhadap materi yang dibahas.

Keempat, pendekatan aksi sosial. Pendekatan aksi sosial ini merupakan gabungan dari pendekatan trasformatif dengan berbagai aktivitas yang berorientasi pada perubahan sosial. Pendekatan ini bertujuan memperkaya keterampilan peserta didik dalam melakukan aksi sosial seperti resolusi konflik, rekonsiliasi keberagaman, dan perbedaan budaya. Penerapan pendekatan ini tidak hanya mengikutsertakan peserta didik untuk memahami dan mempertanyakan isu-isu sosial, melainkan sekaligus juga dilibatkan dalam melakukan sesuatu yang penting berkenaan dengan isu tersebut.

Seperti yang telah disinggung dalam bab sebelumnya, bahwa Pesantren Mahasiswa Unisma dalam upayanya menumbuhkan kesadaran multikultural dalam diri mahasiswanya belum memiliki kurikulum khusus yang didesain berdasarkan nilai-nilai pendidikan multikultural. Artinya, jika kemudian temuan tersebut dihubungkan dengan pendekatan pendidikan multikultural James A. Bank ${ }^{15}$, maka Pesantren Unisma masih pada taraf pendekatan aditif. Yaitu dengan penambahan muatan-muatan, tema-tema, dan perspektif-perspektif ke dalam kurikulum tanpa mengubah struktur dasarnya.

${ }^{15}$ James A. Banks, ed., The Routledge International Companion to Multicultural Education, Routledge International Handbook Series (New York; London: Routledge, Taylor \& Francis Group, 2009), 34. 
Dari paparan hasil penelitian nampak bahwa Unisma memiliki beberapa kegiatan yang sarat akan nilai-nilai pendidikan multikultural. Dimana kegiatan tersebut terpolakan menjadi dua, yaitu multicultural knowing dan multicultural feeling, yang dari keduan kegiatan tersebut mahasiswa terarahkan untuk sampai pada kondisi multicultural action.

Sementara itu, dalam teori pembentukan karakter Thomas Lickona $^{16}$, disebutkan adanya tiga komponen yang diperlukan kaitannya dengan pembentukan karakter seseorang. Ketiga komponen itu adalah adalah moral knowing yang terkait dengan aspek kognitif; moral feeling yang erat kaitannya dengan aspek afektif dan moral action yang merupakan wujud dari aspek psikomotorik. Gambar dibawah ini dijelaskan hubungan saling keterkaitan antara tiga komponen.

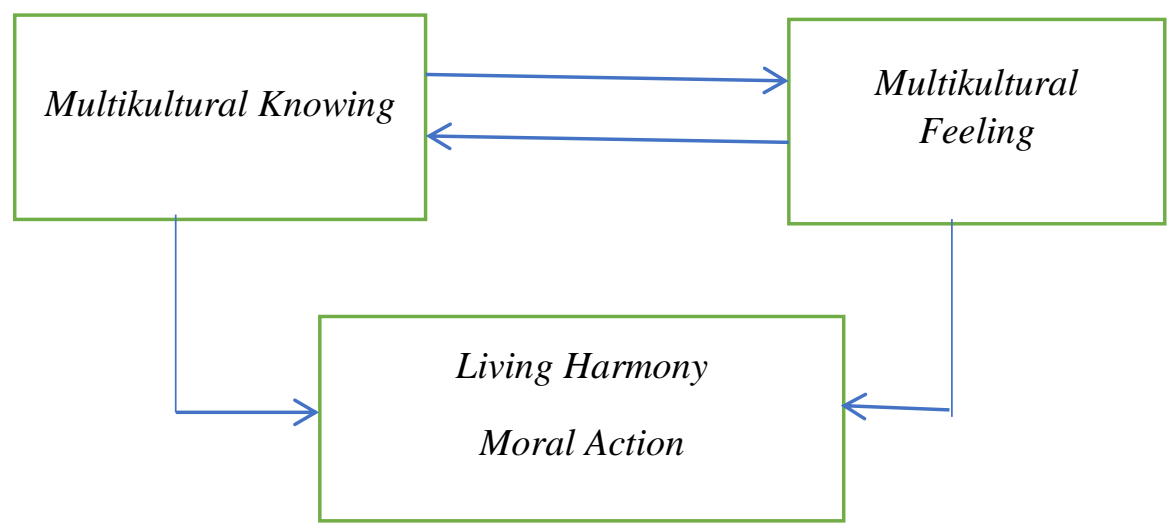

Ketersalinghubungan antar tiga komponen dalam teori pembentukan karakter tersebut juga berlaku dalam kegiatan penanaman nilai-nilai pendidikan multikultural yang ada di Pesantren Unisma. Gambar berikut akan mengilustrasikan ketersalinghubungan

16 Thomas Lickona, Educating for Character: How Our Schools Can Teach Respect and Responsibility (New York: Bantam Books, 2009), 34. 
antara komponen-komponen dalam penenaman nilai-nilai pendidikan multikultural di Unisma.

Gambar tersebut di atas memberikan gambaran bahwa ada tiga komponen yang itu saling terkait satu sama lain. Pertama adalah multicultural knowing, ini dimaknai sebagai penanaman pengetahuan tentang kemultikulturalan. Multicultural knowing ini diberikan Unisma kepada para mahasiswa melalu beberapa program dan kegiatan, diantaranya melalui Orientasi Kehidupan Kampus Mahasiswa Baru (Oshika Maba), Halaqoh Diniyah, dan kegiatan pengaiian rutinan dan kegiatan diskusi mahasiswa.

Kedua adalah multicultural feeling, yaitu penanaman "rasa" multikultural dalam diri para mahasiswa atau dalam istilah lain dikenal sebagai aspek afektif. Untuk menumbuhkan multicultural feeling ini, di samping melalui kegiatan-kegiatan keseharian, Unisma juga memiliki kegiatan Student Day yang wajib diikuti oleh semua mahasiswa semester awal selama sembilan minggu. Melalui kegiatan ini, pengetahuan tentang multikultural para mahasiswa dikembangkan menjadi multicultural feeling. Sehingga, mereka tidak hanya tahu tentang multikultural, melainkan juga meyakini dengan sepenuhnya bahwa multikultural adalah realita yang ada di sekitar mereka yang harus mereka terima dengan sikap yang positif ${ }^{17}$.

Keadaan sosial budaya yang ada di Indonesia seperti yang telah banyak disinggung sebelumnya terdiri dari berbagai macam perbedaan. Ini pada akhirnya menjadikan pendidikan Islam yang ada di Indonesia dengan berdasarkan landasan sosiologis juga untuk mengakomodir keberagaman yang ada. Sehingga, pendidikan Islam

${ }_{17}$ Ngainun Naim and Achmad Sauqi, Pendidikan Multikultural: Konsep Dan Aplikasi, Cet. 1 (Depok, Sleman, Jogjakarta: Ar-Ruzz Media: Didistribusikan oleh Ar-Ruzz Media Group, 2008), 56. 
tidak hanya dimaknai sebagai pendidikan yang berwawasan keislaman, melainkan lebih dari itu, pendidikan Islam adalah pendidikan yang berwawasan Islam yang juga berbasiskan multikultural.

Namun demikian, harus disadari bahwa untuk menyelenggarakan pendidikan muliktultural ini tidaklah mudah. Karena terdapat beberapa syarat yang perlu dipenuhi sebelum suatu lembaga pendidikan menyelenggarakan pendidikan yang berbasiskan mulikultural. Salah satu syaratnya adalah adanya kurikulum yang didesain berdasarkan nilai-nilai multikultural ${ }^{18}$. Dalam hal ini, Pesantren Unisma dengan tidak adanya kurikulum multikultural memang belum bisa dikatakan menerapkan pendidikan multikultural.

Meskipun begitu, Pesantren Unisma tetap memiliki komitmen dalam rangka menumbuhkan kesadaran multikultural pada mahasiswanya, yaitu melalui penenaman nilai-nilai pendidikan multikultural di lingkungan Unisma melalui beberapa kegiatan yang ada. Adapaun nilai-nilai pendidikan multikultural yang ditanamkan pada para mahasiswa ini yang sesuai dengan rekomendasi dari UNESCO $^{19}$ yang juga mendapatkan legitimasi dalam al-Qur'an dan Hadist adalah: nilai toleransi, kebebasan, kesetaraan dan keadilan.

Dalam rangka menanamkan nilai-nilai pendidikan multikultural sebagaimana di sebut di atas, Unisma memiliki beberapa prinsip, yang antara lain: keterbukaan, toleransi, kesatuan dalam perbedaan, dan Islam rahmatan lil'alamin sebagai leader. Prinsipprinsip jika dilihat dari prinsip-prinsip pendidikan Islam multikultural,

${ }^{18}$ Aly, Pendidikan Islam Multikultural Di Pesantren, 56.

${ }^{19}$ Matthew T. Brodhead et al., 'An Evaluation of a Brief Multiple-Stimulus Without Replacement Preference Assessment Conducted in an Electronic Pictorial Format', Journal of Behavioral Education 25, no. 4 (1 December 2016): 32, https://doi.org/10.1007/s10864-0169254-3. 
maka akan nampak beberapa kesamaan. Tabel berikut akan memberikan gambaran yang lebih jelas kaitannya dengan prinsipprinsip penanaman nilai-nilai pendidikan multikultural ini.

Internalisasi nilai ${ }^{20}$ dimulai dengan tahap transformasi nilai yang pada tahap ini peserta didik diberikan pemahaman tentang nilainilai yang hendak diinternalisasikan. Dalam tahap ini, informasi hanya diberikan secara sepihak, artinya peserta didik hanya pasif menerima informasi tentang nilai dari pendidik atau mentornya. Di Pesantren Unisma, tahap ini merupakan multicultural knowing yang memang fokus kegiatan yang ada hanya bersifat penyampaian materi yang bersifat satu arah.

Kemudian, tahap internalisasi selanjutnya adalah transaksi nilai. Berbeda dengan transformasi nilai, pada tahap ini dilakukan komunikasi dua arah, atau interaksi yang bersifat interaksi timbal balik. Selain itu, pada tahap ini informasi tentang nilai yang baik dan buruk dilaksanakan dan diberikan contoh amalan yang nyata dengan diminta memberikan respon. Hal ini dileaksanakan agar peserta didik benar-benar merasakan langsung akan pentingnya nilai-nilai yang sedang diinternalisasikan pada mereka. Di Pesantren Unisma, tahap transaksi nilai ini dilaksanakan dalam kegiatan student day yang merupakan bagian dari tahap/komponen multicultural feeling. Karena dalam kegiatan ini, mahasiswa dihadapkan pada kondisi bagi mereka untuk bisa bertoleransi, adil, dan melaksanakan kewajiban dan memiliki hak yang sama.

Terakhir dalam proses internalisasi nilai adalah transinternalisasi nilai, yang di Unisma adalah multiculural action. Multicultural action dimaksud adalah mahasiswa Pesma Unisma dapat

${ }^{20}$ Muhaimin, Strategi Belajar Mengajar, Cet. 5 (Surabaya: Citra Media, 1996), 89. 
hidup bersama dalam suasana damai yang ini ditunjang dengan kepemilikan sikap-sikap yang didasarkan pada nilai-nilai multikultural. Sehingga, pemahaman ini bisa dipertemukan kesamaannya dari apa yang dimaksud dalam transinternalisasi nilai yang dimaknai sebagai komunikasi dan kepribadian yang masing-masing terlibat secara aktif.

\section{Implikasi Internalisasi Nilai Multikultural di Pesma Unisma}

Salah satu faktor yang mempengaruhi pembentukan sikap seseorang adalah lembaga pendidikan dan lembaga keagamaan. Hal ini dikarenakan keduanya meletakkan dasar pengertian dan konsep moral dalam diri individu. Pemahaman akan baik dan buruk, garis pemisah antara sesuatu yang boleh dan tidak boleh dilakukan, diperoleh dari pendidikan dan dari pusat keagamaan serta ajaranajarannya.

Kaitannya dengan sikap toleransi ini, juga masih relevan jika dihubungkan dengan teori pembentukan karakter yang telah disinggung pada pembahasan sebelumnya. Bahwa dalam teori tersebut disebutkan terdapat tiga komponen dalam upaya pembentukan karakter. Moral knowing, moral feeling dan moral action. Komponen yang terakhir inilah yang juga bisa dimaknai sebagai sikap itu sendiri. Karena sikap itu sendiri memiliki arti ekspresi perasaan (inner feeling) yang mencerminkan apakah seseorang senang, suka atau tidak suka, setuju atau tidak setuju terhadap suatu objek. Dari sini kemudian dapat diambil satu pemahaman bahwa sikap toleransi adalah sikap yang memandang bahwa setiap orang memiliki kebebasan untuk mengekspresikan apa yang menjadi pendapatnya ${ }^{21}$, dalam berbagai hal.

\footnotetext{
${ }^{21}$ Kevin Osborn, The V alues Library Tolerance. (Rosen, 1992), 45.
} 
Tidak hanya berhenti sampai di sini, bahwa ternyata jika dilihat dari segi komponen sikap itu sendiri, yang dalam hal ini adalah sikap toleransi, terdapat pula tiga komponen yang seperti dalam teori pembentukan karakter Thomas Lickona saling menunjang satu sama $\operatorname{lain}^{22}$. Pertama, kognitif, yang merupakan representasi apa yang dipercayai oleh individu pemilik sikap, dimana komponen ini berisi kepercayaan stereotipe yang dimiliki individu mengenai sesuatu dapat disamakan penanganan (opini) terutama apabila menyangkut masalah isu atau problem yang kontroversial.

Kedua, komponen afektif yang lebih menekankan aspek emosional. Aspek emosional inilah yang biasanya berakar paling dalam sebagai komponen sikap dan merupakan aspek yang paling bertahan terhadap pengaruh-pengaruh yang mungkin adalah mengubah sikap seseorang komponen afektif disamakan dengan perasaan yang dimiliki seseorang terhadap sesuatu. Ketiga, komponen konatif yang lebih memiliki kecenderungan ke arah berperilaku atau bereaksi tertentu sesuai dengan sikap yang dimiliki oleh seseorang.

22 Thomas Lickona, Raising Good Children: Helping Your Child through the Stages of Moral Development (New York: Bantam Books, 1983), 67, http:/ / search.ebscohost.com/login.aspx?direct $=$ true\&scope $=$ site $\& \mathrm{db}=$ nlebk\&db $=$ nlabk\&A $\mathrm{N}=733039$. 


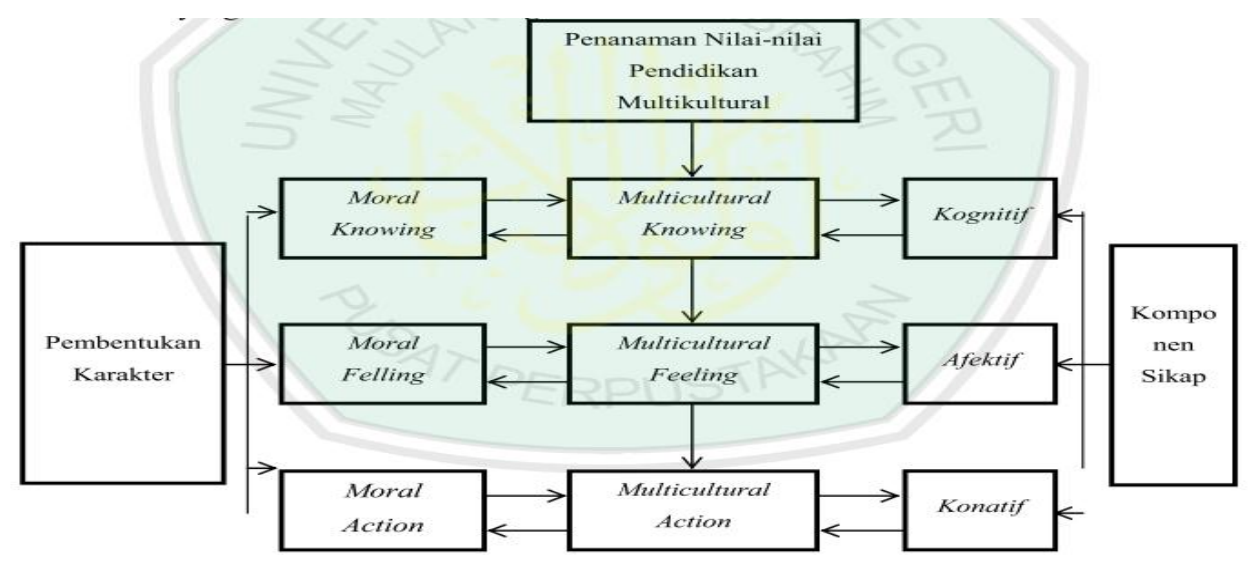

Pada gambar di atas nampak adanya ketersalinghubungan antara domain-domain yang ada dalam pendidikan multikultural dengan komponen pembentukan karakter dan juga kaitannya dengan komponen sikap. Sehingga, ketika berbicara tentang sikap toleransi maka tidak bisa dilepaskan dari domain multicultural action.

Dari Gambar juga dapat dipahami satu keterkaitan antara penanaman nilai-nilai pendidikan multikultural dengan sikap toleransi yang merupakan sikap yang paling ditekankan di Unisma. bahwa sikap toleransi bisa terbagi menjadi tiga, yaitu bersikap pada taraf kognitif, afektif dan konatif. Macam- macam sikap ini tergantung dari bagaimana penanaman nilai-nilai pendidikan multikultural itu sudah dilaksanakan. Artinya, ketika penanaman nilai-nilai pendidikan multikultural itu hanya berhenti di multicultural knowing, maka sikap toleransi yang didapatpun hanya sebatas pengetahuan.

Kemudian ketika penanaman nilai-nilai pendidikan multikultural tidak hanya berhenti pada multicultural knowing, melainkan juga pada multicultural feeling atau bahkan sampai pada multicultural action. Maka sikap toleransi yang kemudian di miliki para mahasiswa atau peserta didik tidak hanya pada taraf mengetahui saja bahwa toleransi itu penting. Tetapi mereka benar-benar merasakan 
sendiri akan pentingnya untuk memiliki sikap toleransi di dalam masyarakat yang beragam ini. Hingga pada akhirnya, karena sudah merasakan sendiri akan pentingnya sikap toleransi itu, mereka pun pada bisa memiliki sikap toleransi yang di domain konatif atau dalam teori pembentukan karakter disebut moral action.

Sementara itu, ada pula ketersalinghubungan antara hubungan sikap toleransi ini dengan penanaman nilai-nilai pendidikan multikultural dengan tingkatan sikap secara umum. Bahwa disebutkan jika sikap secara umum memiliki tingkatan. Adapun tingkatan itu adalah sebagai berikut: ${ }^{23} 1$ ) Menerima (receiving), artinya seseorang (subyek) mau dan memperhatikan stimulus yang diberikan (obyek); 2) Merespon (responding), yaitu memberikan jawaban apabila ditanya, mengerjakan dan menyelesaikan tugas yang diberikan adalah suatu indikasi sikap karena dengan suatu usaha untuk menjawab pertanyaan atau mengerjakan tugas yang diberikan. Terlepas pekerjaan itu benar atau salah adalah berarti orang itu menerima ide tersebut; 3) Menghargai (valuing), mengajak orang lain untuk mengerjakan atau mendiskusikan dengan orang lain terhadap suatu masalah; 4) Bertanggung jawab (responsible). Bertanggung jawab atas segala sesuatu yang telah dipilihnya dengan segala resiko adalah mempunyai sikap yang paling tinggi.

${ }^{23}$ Zubaedi, Desain Pendidikan Karakter, Konsepsi Dan Aplikasinya Dalam Pendidikan (Jakarta: Kencana Prenada, 2011), 98; Benjamin S Bloom, David R Krathwohl, and Bertram S Masia, Taxonomy of Educational Objectives: The Classification of Educational Goals (New York: Longman, 1964), 34. 


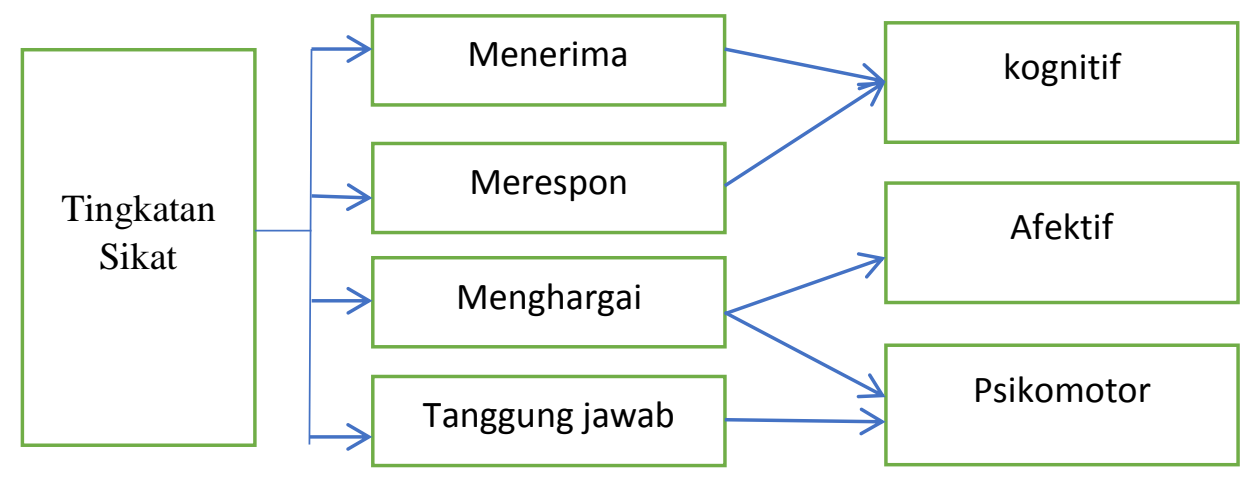

Dalam Gambar terlihat pada tingkatan menerima dan merespon masuk pada ranah kognitif. Di mana subyek menerima dan memperhatikan apa yang diberikan kepadanya. Adapun pada tingkatan merespon, penulis menempatkannya pada ranah kognitif juga karena dalam pengertiannya sendiri merespon di sini adalah mengerjakan apa yang ditugaskan kepada subyek, terlepas apakah subyek itu tahu akan kebenaran dari pekerjaan yang diberikannya atau tidak.

Kemudian pada tingkatan menghargai, penulis menempatkannya ke dalam ranah afektif dan juga konatif. Hal ini berdasarkan dari definisi dari tingkatan menghargai itu sendiri, bahwa pada tingkatan ini seseorang mengajak orang lain untuk mendiskusikan suatu masalah. Kesediaan untuk mengajak orang lain untuk mendiskusikan apa yang menurut subyek adalah masalah merupakan indikasi bahwa subyek ini sudah melalui komponen sikap afektif, dimana subyek ini sudah melibatkan aspek emosional. Mengajak untuk berdiskusi ini juga sudah menjadi langkah awal yang menuju pada ranah komponen konatif. Terakhir adalah 
bertanggungjawab, yaitu bertanggung jawab atas apa yang dilaksanakan.

Dari sekian panjang pembahasan tentang sikap toleransi ini, dapat diambil satu kesimpulan umum bahwa sikap toleransi ini menjadi salah satu tujuan akhir dari penanaman nilai-nilai pendidikan multikultural. Yang mana jika dilihat dari segi komponen sikap, sikap toleransi ini ada di posisi sikap konatif. Kemudian ketika dilihat dari segi pembentukan karakter, sikap toleransi ini berada di bagian moral action.

Adapun dari paparan data yang telah dibahas dalam bab sebelumnya, nampak adanya perubahan sikap toleransi ke arah yang lebih positif. Artinya, sikap ini memiliki kecenderungan tindakan ke arah mendekati, menyenangi, dan mengharapkan obyek tertentu, yang dalam hal ini adalah terkait dengan perbedaan latar belakang para mahasiswa yang pada awalnya memiliki penilaian negatif kepada orang lain yang berbeda telah berubah menjadi penilaian yang positif, yang awalnya saling mencurigai pada akhirnya dapat berteman dekat dengan baik.

\section{Kesimpulan}

Berdasarkan uraian dan analisis tentang INTERNALISASI NILAI MULTIKULUTURAL DALAM MENGEMBANGKAN SIKAP TOLERANSI ( Studi di Di Pesantren Mahasiswa Universitas Islam Malang) diperoleh kesimpulan sebagai berikut:

1. Implementasi penanaman nilai-nilai pendidikan multikultural dilaksanakan menggunakan kegiatan-kegiatan yang meliputi multicultural knowing dan multicultural feeling. Multicultural knowing adalah kegiatan-kegiatan yang di dalamnya memuat pengetahunpengetahuan tentang nilai-nilai pendidikan multikultural. 
Penanaman ini diberikan kepada mahasiswa Unisma melalui beberapa kegiatan, yaitu pada kegiatan Orientasi Kehidupan Kampus Mahasiswa Baru (Oshika Maba), Halaqoh Diniyah dan mata kuliah Agama Islam 1 sampai 5. Sementara itu, multicultural feeling adalah penanaman rasall multikultural dalam diri para mahasiswa atau dalam istilah lain dikenal sebagai aspek afektif. Untuk menumbuhkan multicultural feeling ini, di samping melalui kegiatan-kegiatan keseharian, Unisma juga memiliki kegiatan Student Day. Melalui kegiatan ini pengetahuan tentang multikultural para mahasiswa dikembangkan menjadi multicultural feeling. Sehingga, mereka tidak hanya tahu tentang multikultural, melainkan juga meyakini dengan sepenuhnya bahwa multikultural adalah realita yang ada di sekitar mereka yang harus mereka terima dengan sikap yang positif. Dari penamanam multicultural knowing dan multicultural feeling inilah mahasiswa Unisma diharapkan bisa hidup bersama secara harmonis perbedaan (living in harmony). Dapat hidup bersama dalam suasana damai dan rukun dengan tetap saling menghormati dan menghargai segala bentuk perbedaan. Adapun nilai-nilai pendidikan multikultural yang ditanamkan di Unisma diantaranya: toleransi, demokrasi, kesetaraan, dan keadilan.

2. Penanaman nilai-nilai pendidikan multikultural memberikan dampak positif terhadap sikap toleransi mahasiswa Unisma. sikap positif ini berupa ketidakengganan mahasiswa untuk berinteraksi dan bekerjasama dengan siapa saja dengan nyaman tanpa ada dikap saling curiga. Sikap toleransi ini juga termasuk salah satu bagian dalam multicultural action, dimana hidup bersama dalam 
suasana yang harmonis hanya bisa dicapai jika setiap mahasiswa memiliki sikap toleransi.

\section{E. Referensi}

Aly, Abdullah. Pendidikan Islam Multikultural Di Pesantren: Telaah Terbadap Kurikulum Pondok Pesantren Modern Islam Assalam Surakarta. Cet. 1. Yogyakarta: Pustaka Pelajar, 2011.

Azra, Azyumardi. 'Kontestasi Pemikiran Islam Indonesia Kontemporer'. Studia Islamika 23, no. 1 (30 April 2016): 175-84. https://doi.org/10.15408/sdi.v23i1.2905.

Bahri, Syamsul. 'Internalisasi Nilai-Nilai Multikulturalisme Dengan Pendekatan Aditif Dalam Pembelajaran Pai Di Sekolah Dasar Taman Harapan', n.d.

Banks, James A. An Introduction to Multicultural Education. Sixth edition. Boston: Pearson Education, 2017.

, ed. The Routledge International Companion to Multicultural Education.

Routledge International Handbook Series. New York ; London:

Routledge, Taylor \& Francis Group, 2009.

Bloom, Benjamin S, David R Krathwohl, and Bertram S Masia. Taxonomy of Educational Objectives: The Classification of Educational Goals. New York: Longman, 1964.

Bogdan, Robert, and Sari Knopp Biklen. Qualitative Research for Education: An Introduction to Theory and Methods. 3rd ed. Boston: Allyn and Bacon, 1998.

Brodhead, Matthew T., Emily A. Abel, Monerah N. Al-Dubayan, Lauren Brouwers, Gina Warren Abston, and Mandy J. Rispoli. 'An Evaluation of a Brief Multiple-Stimulus Without Replacement Preference Assessment Conducted in an Electronic Pictorial 
Format'. Journal of Behavioral Education 25, no. 4 (1 December 2016): 417-30. https://doi.org/10.1007/s10864-016-9254-3.

Creswell, John W. Educational Research: Planning, Conducting, and Evaluating Quantitative and Qualitative Research. 4th ed. Boston: Pearson, 2012. Denzin, Norman K., and Yvonna S. Lincoln, eds. The SAGE Handbook of Qualitative Research. 3rd ed. Thousand Oaks: Sage Publications, 2005.

Efendi, Nur. 'Pengembangan Pendidikan Islam Plural-Multikultural'. Ta'allum: Jurnal Pendidikan Islam 1, no. 1 (2013): 13-28.

JR Raco. Metode penelitian Kuantitatif Jenis, Karakteristik dan Keunggulanya. Bandung: Alfabeta, 2014.

Lexy J, Moloeng. Metodologi penelitian Kualitatif. 29th ed. Bandung: Rosdakarya, 2011.

Lickona, Thomas. Educating for Character: How Our Schools Can Teach Respect and Responsibility. New York: Bantam Books, 2009.

- Raising Good Children: Helping Your Child through the Stages of Moral Development. New York: Bantam Books, 1983. http:/ / search.ebscohost.com/login.aspx?direct=true\&scope $=$ sit $\mathrm{e} \& \mathrm{db}=$ nlebk\&db=nlabk\&AN=733039.

Miles, Matthew B., A. M. Huberman, and Johnny Saldaña. Qualitative Data Analysis: A Methods Sourcebook. Third edition. Thousand Oaks, Califorinia: SAGE Publications, Inc, 2014.

Muhaimin. Strategi Belajar Mengajar. Cet. 5. Surabaya: Citra Media, 1996.

Musyarofah, Musyarofah. 'Internalisasi Pesan Multikultural Pada Organisasi Pesantren Putri Stain Jember'. Inject Interdisciplinary Journal of Communication) 1, no. 2 (2016): 181-202. 
Naim, Ngainun, and Achmad Sauqi. Pendidikan Multikultural: Konsep Dan Aplikasi. Cet. 1. Depok, Sleman, Jogjakarta: Ar-Ruzz Media: Didistribusikan oleh Ar-Ruzz Media Group, 2008.

Osborn, Kevin. The V alues Library Tolerance. Rosen, 1992.

Purnomo, Pajar. 'Pengembangan Buletin Kampus Bermuatan Nilai Kebhinekaan Pancasila Untuk Menangkal Radikalisme Pada Mahasiswa STKIP Darussalam Cilacap'. Lingua 13, no. 2 (2017): 143-150.

Sapendi, Sapendi. 'Internalisasi Nilai-Nilai Multikultural Dalam Pembelajaran Pendidikan Agama Islam Di Sekolah (Pendidikan Tanpa Kekerasan)'. Rabeema 2, no. 1 (2015).

Wahyu Etikasari, Nur. 'Persepsi Mahasiswa Program Studi S1 Ppkn Universitas Negeri Surabaya Terhadap Wacana Intoleransi Di Media Sosial'. Kajian Moral dan Kewarganegaraan 6, no. 01 (25 January 2018). http://jurnalmahasiswa.unesa.ac.id/index.php/jurnalpendidikan-kewarganegaraa/article/view/22679.

Yin, Robert K. Case Study Research: Design and Methods, 2013.

Zubaedi. Desain Pendidikan Karakter, Konsepsi Dan Aplikasinya Dalam Pendidikan. Jakarta: Kencana Prenada, 2011. 